\section{Missteps and mistakes, friends and heroes}

\section{Elaine A Ostrander}

Cancer Genetics Branch, National Human Genome Research Institute/National Institutes of Health, 50 South Drive, Room 5351, Bethesda, Maryland 20892, USA

(Correspondence should be addressed to E A Ostrander; Email: eostrand@mail.nih.gov)

Endocrine-Related Cancer (2012) 19 P5-P8

'There is that moment in discovery where you are the only person in the world who understands how something in biology works - the only person - a small secret between you and Nature, just for a few moments...'

With those words ringing in my head, spoken by a scientist at some program, I have long since forgotten, I joined the Department of Microbiology and Immunology at the Oregon Health Sciences University (OHSU) in 1981 to begin my journey as a research scientist. In truth, I had arrived at that point in my life in a rather roundabout way. My parents had raised my brother, sister, and me in an environment where academics was paramount. My father was a librarian and books were everywhere in our New Jersey apartment. When my dad worked after-hours at the library, my brother and I would sprawl on the library floor reading and drinking Orange Fanta. My brother, who you will discover is one of my heroes, gravitated toward adventure books, eventually becoming a marine biologist. By comparison, I read about animals, never expecting it to be so foretelling.

I had always figured I might be a teacher and I was content with that notion, until the day of my high school biology final. My perfect record of straight A's was broken with a single Genetics question. 'If a woman is pregnant with a child and she currently has 9 boys and one girl, what is the chance she will have a girl?' The right answer was, of course, 50:50. But

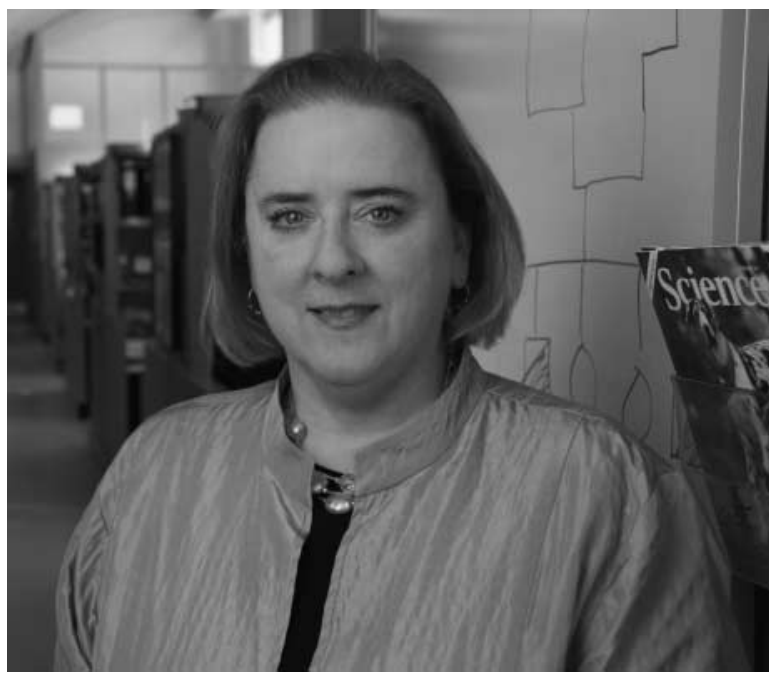

I answered one out of ten. I was very wrong, and very angry. 'It was a trick question, it wasn't fair, and I'd been cheated out of my perfect grade'. In that singular moment, I decided to become a geneticist. I had found something that challenged me.

While scholarships paid my tuition, my college years were spent working at odd jobs to pay living expenses. Desperate for money I picked fruit, was a diener (look it up), tutored calculus, cleaned bathrooms, and washed dishes. Finally, I got a terrific job at the University of Washington (UW), with Dr Gottfried Schmer who was developing methods to slow tumor growth by starving tumors of critical amino acids. I learned to pour columns, purify proteins, and run a gas liquid chromatograph. Most importantly, I got my first publication! I was ready for graduate school.

So here's my first little secret. I got into the Oregon Health Sciences University (OHSU) PhD program by mistake. I thought I was applying for a Masters, only to find upon acceptance that the Microbiology program at OHSU didn't offer a Masters and I was actually in a $\mathrm{PhD}$ program! I was too embarrassed to explain I didn't belong. So I figured I'd just stay and see how far I made it. Well, I made it all the way.

My thesis project was to understand nucleosome movement around the replication origin of the SV40 tumor virus, but my mind frequently walked the halls while my hands were busy in the tissue culture hood. Geneticist Mike Litt had recently returned from a sabbatical with Ray White at Utah and he gave an 
amazing lecture regarding restriction fragment length polymorphisms (RFLPS), linkage, and LOD scores. With this technology, one could scan the whole genome with a few hundred Southern blots and find disease loci. I was enthralled. This was what I was going to do with my career. But first I had to finish my lackluster PhD.

So what was most memorable about my PhD? I'd love to tell you it was the highly touted publication of some insightful, paradigm shifting paper. It wasn't. My big moment came the night I dropped one microgram of minichromosome viral DNA that had taken me months to isolate from replicating cells onto my laboratory bench. As I watched the liquid absorb into the bench paper, I saw my $\mathrm{PhD}$ slipping away. To the rescue came fellow grad student Cheryl Maslen. Fortified with a six pack, and everything we collectively knew about organic chemistry, we isolated $90 \%$ of the DNA out of the bench paper. In our euphoria, we wrote a paper on our adventure and submitted it to a biotechniques journal with our names as well as my thesis advisor's name. In the morning, our antics were quickly forgotten and DNA in hand, I proceeded with the last experiments for my thesis. You can imagine our shock when we got an acceptance letter from the journal for our paper entitled 'How to Isolate Critical DNA Samples from Laboratory Bench Paper'. My thesis advisor was NOT amused. But the experience cemented a lifelong friendship with Cheryl and that little methods paper remains, to this day, one of my most requested.

After defending my thesis, I applied for a postdoc fellowship at Harvard working with James Wang on transcription and DNA topoisomerases, setting aside my goal of becoming a geneticist. I didn't have enough money to fly to Boston for an interview, so I drove my little Honda Civic from Oregon to Boston, staying at campgrounds and cheap hotels. The night I arrived in Boston, I snuck into the Kennedy library where I slept the night. I cleaned up the next morning (as best I could) and went to my interview. As it turned out, working with Jim Wang from 1990 to 1993 was the best career decision I ever made. Jim is a person of huge intellect, impeccable character, and old world charm. I learned how to read papers, ask questions, and present data. I learned how to design an experiment and critique my own work. For the first time, I learned to believe in myself and my ideas. I made lifelong friends and eventually met the man who became my husband.

After three great years in the Wang laboratory, I went to Berkeley to do a fellowship on plant biology with the intent of studying HOX genes during Arabidopsis development. But fate has a way of stepping in when you deviate too far from life's plan. When I arrived at Berkeley, there was no bench available in the laboratory and my new mentor was headed for maternity leave. So I decided to take a temporary postdoc with Jasper Rine, beginning what was to become my lifelong love, the Dog Genome Project.

As always, timing is everything. Just a short time before I began my mini postdoc, two papers were published in the American Journal of Human Genetics reporting that microsatellites, amplified by PCR, could take the place of RFLPs for doing linkage, one by my old friend Mike Litt. I saw the application to my own work. I could rapidly make a map and then find genes for diseases, behavior, and anything else that looked interesting.

It's always the person across the hall or the next building over that changes my life plan. In 1984, it was Mike Litt and in 1992 it was Mary-Claire King. When I met her, Mary-Claire was working with Jeff Hall on the now famous Science paper localizing BRCAl to chromosome $17 \mathrm{q} 21$. She allowed me the privilege of attending her laboratory meetings at Berkeley and I learned years of human genetics in just months. So many people helped me translate the advances of human genetics to the dog, and I remain grateful to all the people who were part of the King laboratory during that extraordinary time.

In 1993, I went to the Fred Hutchinson Cancer Research Center as an Assistant Member, finally achieving my goal of running a genetics laboratory. I will always be grateful to Rainer Storb for helping ease that transition. I couldn't decide between human genetics and the dog work, and so I pursued both, as I still do today. Drs Kathleen Malone, Janet Daling, Amy Langston, and I were the first to study the frequency and distribution of $B R C A 1$ and $B R C A 2$ mutations in young women from the general population using a population-based, case-control study. The resulting papers were, and remain, highlights of my career. A phone call from Janet Stanford pulled me into prostate cancer genetics, which has proven challenging to unravel. We've crossed cultures time and again to produce papers that make substantive contributions to the field and are particularly interested in aggressive disease. After nearly 20 years, I still look forward to our daily talks and emails. Janet always pushes me to think bigger than I am programed to, and the result is our collection of some 80 joint papers.

The other half of my laboratory initially worked on building canine linkage maps and, with Francis Galibert, Greg Acland, and Matthew Breen, physical maps of the dog genome. As it became clear that the dog system worked, a host of collaborators used the maps to identify disease genes. We wrote several 
collaborative papers, ultimately contributing to both human and canine health. The icing on the cake was a $P N A S$ paper by Dr Gordon Lark and Kevin Chase showing that one could use the map to identify quantitative trait loci (QTLs) linked to morphological traits like body size.

With the publication of the LARK paper, two things became clear. First, I guessed, correctly, that we had enough successes that we could convince NIH to fund the sequencing of the dog genome, as they did in 2003. Secondly, with the resulting SNP chip, it was possible to map breed-fixed traits. We learned why some breeds are big and others are small, why some breeds have long legs and others short. We are now mapping cancer genes and are especially interested in those that have proven intractable through studies of human families and populations. Our work has been well received, and I have learned more than I ever imagined from the most talented group of students and postdocs a mentor could ever wish for.

So our lives settled into a routine of grants, experiments, papers, and meetings. However, just when you think you have things under control, life tosses a complexity. The birth of our first daughter in 2002 on Halloween night, following a difficult and dangerous pregnancy, could not have been more joyous. She was unexpectedly perfect in every way.

She also taught me to use my time more wisely. There are no magic formulas for being a successful mom in science. I learned to feed my daughter while talking on the phone, to sneak her into my office on weekends while I wrote grants, and to entertain her by sneaking my dog in as well. Our daughter could sort flies by eye color for my husband by the time she was four, and she's been to more dog shows than I can count. Tenure came, and I can't say having a child made it harder or easier, just different. I had to be organized, flexible, and creative.

When my daughter got to preschool and life got easier, I thought I'd go back to my workaholic schedule. But I missed the quiet moments my daughter and I had shared at night, just the two of us, whispering to each other. I like firsts and I wanted them again; first steps, first laughs, first words. So in 2005, I found myself on a plane to China to adopt a beautiful 2-year-old girl with a cleft lip and palate who had been living in an orphanage since birth. Because of her affliction, she had never spoken. But miracle working surgeons at Johns Hopkins took care of all that and she is now a first-grade chatterbox. I was the one to hear her first word and I was the proud recipient of her life's very first kiss. Indeed, I do like firsts.

For the last 7 years, I have been at the National Human Genome Research Institute at NIH, working alongside amazing colleagues. In addition to my science, I've become something of a steward. I like to think our laboratory produces papers of high quality because of the dedication and character of those at the bench, and it's my job to make sure that they stay the course. It's also my privilege to offer mentorship to faculty early in their careers who are facing the same challenges I did just a few years ago.

Early career graduate students often tell me about their scientific heroes and ask me who mine are. Truthfully, I'm unsure about the concept - no one is infallible. But after some thought, here is my short list, selected from scientists that I have known, and who have changed, or challenged, me. First, I choose my brother Gary, because more than anyone I know he perseveres in his goals. Secondly, geneticist Gordon Lark from the University of Utah is on the list because he is a visionary. He saw the utility of developing the Portuguese water dog system long before we had even built a linkage map. Next, I'd list evolutionary biologist Robert Wayne because he is a rigorous thinker with unflinching integrity. Fourth, I'd list seer Lee Hood, who can literally predict the future. Carlos D Bustamante is a must because of his generous spirit. Finally, I would include Barb Trask, for all the times she saw me cry, but pretended not to; she has compassion.

And this brings me full circle to what I tell my trainees they must have to succeed in science. They must be persistent, productive, and visionary. They should be rigorous scientists but compassionate people who are generous with both ideas and credit. Finally, and above all, they should pursue questions they are passionate about. I can't say I've always hit the mark on all of these, all the time. But I am still in love with my science and, so far at least, the ride has been great.

\section{Declaration of interest}

The author declares that there is no conflict of interest that could be perceived as prejudicing the impartiality of this profile.

\section{Funding}

Throughout her career, Dr Ostrander has been funded by NIH, ACS, and DOD grants. She is currently funded by the Intramural Program of the National Human Genome Research Institute and grants from the AKC Canine Health Foundation.

\section{Acknowledgements}

This invited editorial reflects the memories and thoughts of the author. I apologize for imperfections, they are mine alone. I acknowledge, first and foremost, the many Ostrander Laboratory students, postdoctoral fellows, and technicians I 
have been privileged to mentor. In particular, Drs Amelia Langston, Jenni Lowe, Heidi Parker, Nathan Sutter, Danielle Karyadi, and Jeffrey Schoenebeck have shown extraordinary insight, talent, and devotion to the projects in the laboratory, and I am grateful to each of you for your generosity of time, ideas, and yes, criticism.

I owe a huge debt of gratitude to Gottfried Schmer at the UW, Lesley Hallick at OHSU and Rainer Storb at the FHCRC for giving me academic homes and to Eric Green and Dan Kastner at NHGRI for their continuous support. Also, I thank the countless administrators throughout my career who have worked tirelessly behind the scenes to ease my burdens.

This journey would not have been possible, nor can it continue, without the friendship of Drs Cheryl Maslen and
Heidi Parker who, in addition to being outstanding scientists in their own right, have always made our friendship a priority. Thanks to Leonid Kruglyak, Lee Anderson, Francis Galibert, Janet Stanford, Kathi Malone, and Greg Acland. Sharing this journey with each of them has made it truly joyous. There are, of course, many valued collaborators I have not named. Please pardon the omission; I simply ran out of space, and I thank you most dearly.

Most importantly and most sincerely, I thank my husband, who believed in me when I did not believe in myself. You have always been my greatest champion and for your wisdom, patience, and counsel I am deeply grateful. Finally, this paper is dedicated to my father and longtime supporter Richard E Ostrander. 